\title{
Pediatric Sex Cord-Stromal Tumor with Composite Morphology: A Case Report
}

\author{
Jason A. Jarzembowski, * and Richard W. Lieberman \\ Department of Pathology, University of Michigan Hospitals and Clinics, 1500 E. Medical Center Drive, Ann Arbor, \\ Michigan 48109, USA
}

Received June 3, 2005; accepted August 9, 2005; published online October 12, 2005.

\begin{abstract}
A 12-year-old female with developmental delay/mental retardation and a family history of gynecologic cancers presented with nonspecific abdominal complaints and was found to have a $4.5-\mathrm{kg}, 25-\times 23-\times 15-\mathrm{cm}$ pelvic mass with solid and cystic components and associated retroperitoneal and mesenteric lymphadenopathy. Laboratory studies revealed increased serum levels of CA-125 and inhibin B. Histologically, the tumor exhibited several different morphologic appearances including adult granulosa cell tumor, juvenile granulosa cell tumor (with areas of marked atypia), and Sertoli cell tumor. Immunohistochemically, the tumor was positive for calretinin, MIC-2 (CD99), S100 protein, PGP 9.5, and neuron-specific enolase. Electron microscopy of the Sertoli cell tumor-like areas showed Charcot-Bottcher filaments, a distinguishing feature of Sertoli cells. Together, these findings supported a diagnosis of mixed sex cord-stromal tumor including granulosa cell tumor of adult and juvenile types and intermediate- to highgrade Sertoli cell tumor, with large areas of markedly atypical sex cord-stromal tumor.
\end{abstract}

Key words: granulosa cell tumor, ovarian neoplasms, Sertoli cell tumor, sex cord-stromal tumor

\section{CASE REPORT}

A 12-year-old developmentally delayed/mentally retarded female presented with vague abdominal complaints including constipation, bloating, and

*Corresponding author, e-mail: jjarzemb@umich.edu increasing girth. Her medical history was significant for recent onset of menarche at age 12 years with irregular cycles. She had 1 maternal aunt and 1 paternal aunt who were older than 40 years and had ovarian cancer and a grandmother who had endometrial cancer. Physical examination detected a large, firm mass that filled the abdomen and extended from the pubic symphysis to the xiphoid process. Laboratory studies showed increased serum levels of CA-125 (504 U/mL, normal range $0-35 \mathrm{U} / \mathrm{mL})$, inhibin $\mathrm{B}(2,613 \mathrm{pg} / \mathrm{mL}$, normal follicular phase range $16-290 \mathrm{pg} / \mathrm{mL})$, and lactate dehydrogenase (389 IU/L, normal range 60-200 IU/L). Serum levels of $\beta$-human chorionic gonadotropin, $\alpha$-fetoprotein, testosterone, inhibin A, and total calcium were normal. Computed tomogram demonstrated a $23-\times 20-\times 12-\mathrm{cm}$ pelvic mass with solid and cystic components and enlarged retroperitoneal and mesenteric lymph nodes.

Exploratory laparotomy of the abdomen and pelvis revealed a $4.5-\mathrm{kg}, 25-\times 23-\times 15-\mathrm{cm}$, complex right ovarian mass composed of multiple unilocular, smooth-lined cysts filled with brown clear fluid and separated by firm, gray-white, lobulated tissue with focal hemorrhage and necrosis (Fig. 1). The ipsilateral fallopian tube was unremarkable. Tumor implants were found in the rectosigmoid pericolic soft tissue, parauterine soft tissue, omentum, and mesentery. Eleven bilateral peri- 


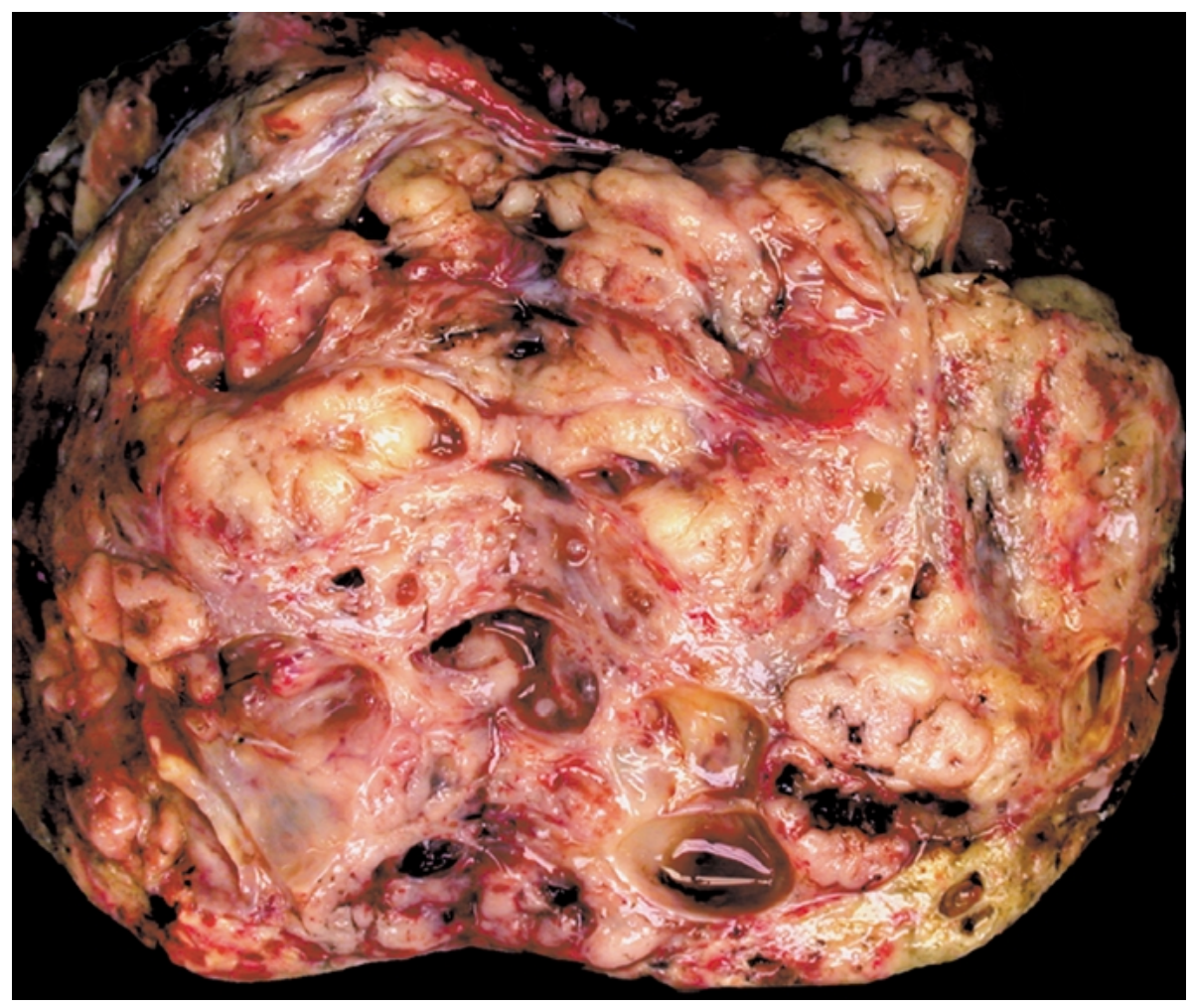

Figure 1. Gross appearance of bivalved right ovarian tumor.

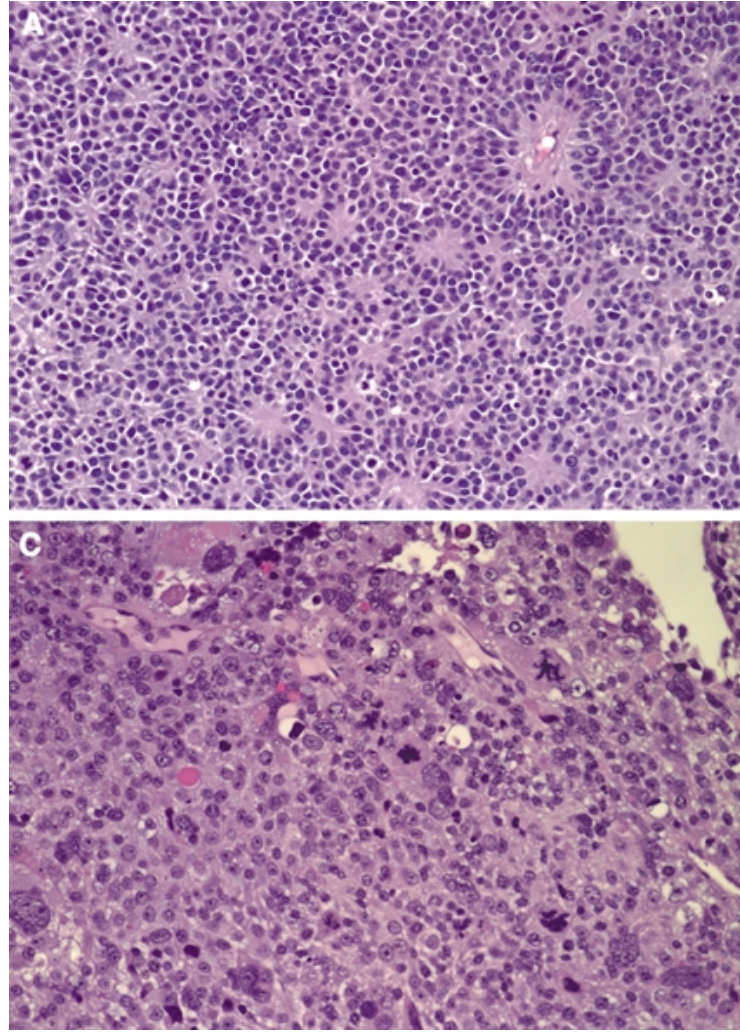

Figure 2. Microscopic appearance of tumor, including areas resembling (A) adult granulosa cell tumor with Call-Exner bodies, (B) juvenile granulosa cell tumor with
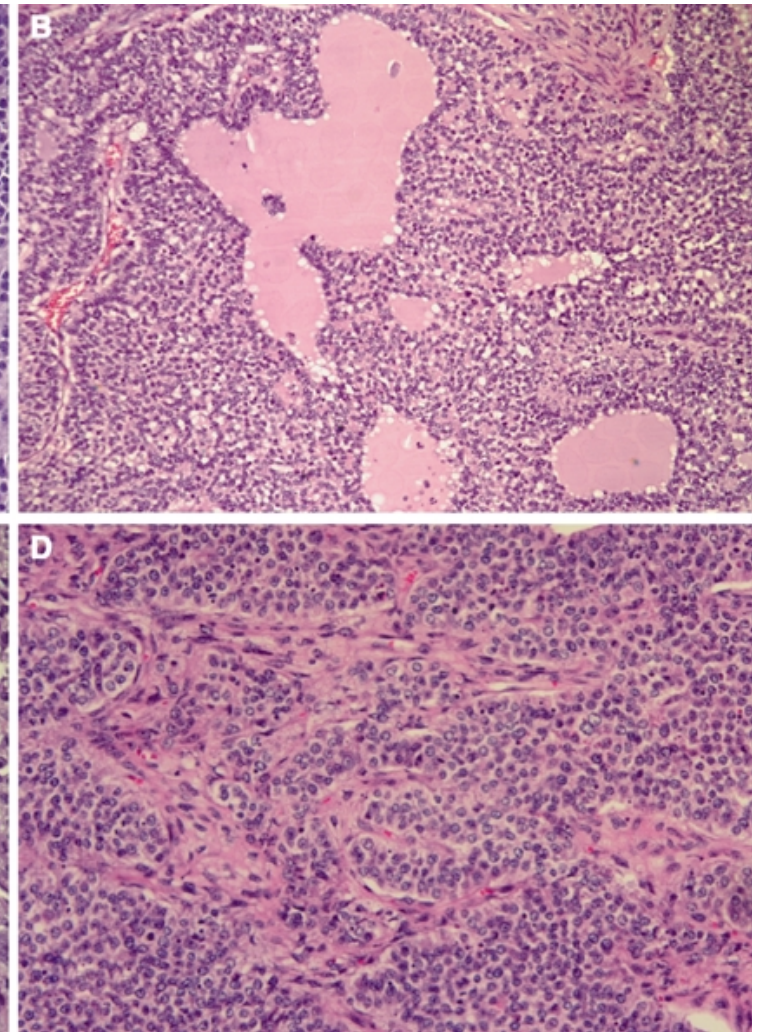

irregular follicles, (C) markedly atypical areas of juvenile granulosa cell tumor, and (D) Sertoli cell tumor. Hematoxylin and eosin, 200x in A, C, D, 100× in B. 


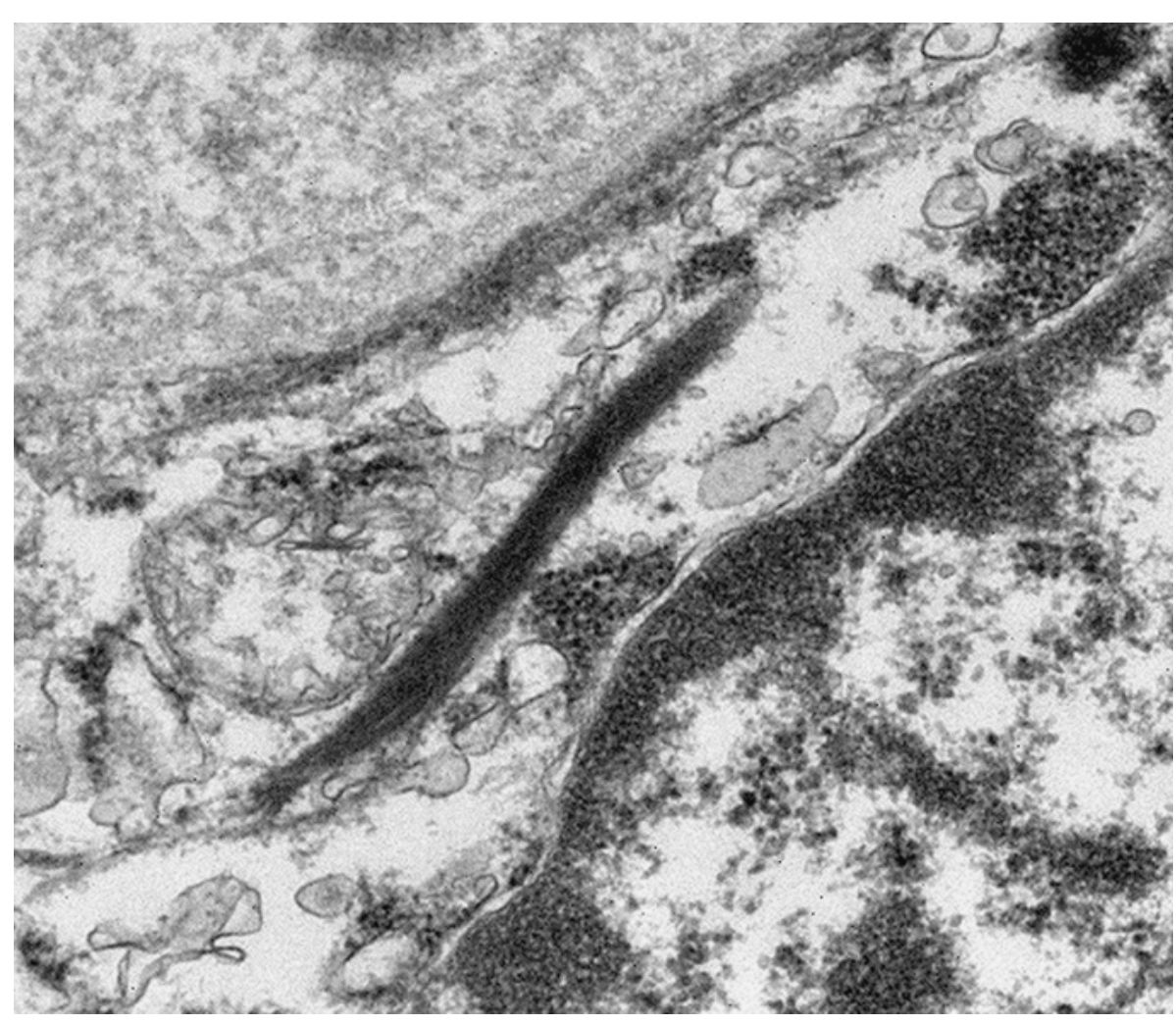

Figure 3. Electron microscopy shows perinuclear, linear filament aggregates consistent with Charcot-Bottcher crystalloids $(80,000 \times)$.

aortic, mesenteric, and pelvic lymph nodes were negative for neoplasm.

Histologically, the tumor consisted of a spectrum of morphologies. Some areas resembled adult granulosa cell tumor (15\%) with trabeculae, diffuse sheets, and Call-Exner body-like structures composed of cells with grooved nuclei and eosinophilic cytoplasm (Fig. 2A). Other areas (10\%) showed juvenile granulosa cell tumor with sheets and occasional, large, irregular follicles composed of cells lacking nuclear grooves (Fig. 2B) $[1,2]$. The predominant appearance $(65 \%)$ was that of markedly atypical solid areas superficially resembling juvenile granulosa cell tumor (Fig. 2C). Portions of the tumor (10\%) resembled Sertoli cell tumor with pale, lipid-filled cells arranged in tubules and trabeculae (Fig. 2D) [3].

Immunohistochemically, the tumor was diffusely positive for MIC-2 (CD99; membranous staining), S100 protein (cytoplasmic), PGP 9.5 (cytoplasmic), and neuron-specific enolase (cytoplasmic) and showed patchy positive staining for calretinin (cytoplasmic); all tumor components expressed each of these antigens, although the most poorly differentiated areas stained less intensely. The tumor was negative for leukocyte common antigen (CD45), $\alpha$-fetoprotein, epithelial membrane antigen, neurofilament protein, smooth muscle actin, desmin, inhibin- $\alpha$, chromogranin, synaptophysin, cytokeratin, and c-kit (CD117). Electron microscopy of Sertoli cell tumor-like areas showed rare cells containing electron-dense filaments in a paranuclear distribution. These structures, known as Charcot-Bottcher filaments, are an ultrastructural characteristic of Sertoli cells (Fig. 3). Polymerase chain reaction and western blot studies for the t(11;22) EWS-FLI translocation (performed at the Armed Forces Institute of Pathology) were equivocal.

\section{DISCUSSION}

Although the histology of much of the tumor suggested a sex-cord stromal origin, the large areas composed of poorly differentiated small round blue cells raised a number of additional possibilities in the differential diagnosis. In the pediatric population this includes Ewing sarcoma/ primitive neuroectodermal tumor, rhabdomyosarcoma, desmoplastic small round cell tumor, and lymphoma. At this age, the most common ovarian neoplasms are germ cell tumors. Small cell carcinoma, hypercalcemic type, was also 
considered based on the morphologic appearance of the tumor. Immunohistochemistry helped narrow the differential because lymphoma is unlikely with negative leukocyte common antigen staining, rhabdomyosarcoma is unlikely with negative desmin staining, and small cell carcinoma of the ovary, hypercalcemic type, or desmoplastic small round cell tumor are unlikely with negative epithelial membrane antigen and keratin staining (and a normal serum calcium) [4]. Although the tumor cells were positive for MIC-2 (CD99), PGP 9.5, and S100 protein, EWS-FLI studies were equivocal, which raises the possibility of, but does not confirm, a diagnosis of primitive neuroectodermal tumor. Consequently, the distinctive morphologic features of the granulosa cell tumor-like and the Sertoli cell tumor-like areas, the increased serum inhibin B levels, calretinin positivity by immunostaining, and electron microscopic demonstration of Charcot-Bottcher filaments support a sex cord-stromal origin [4-6]. Gynandroblastoma was also a diagnostic consideration, but this patient's tumor lacked the classic combination of well-differentiated tubular Sertoli cell elements and microfollicularly patterned granulosa cell elements, presented at a later than expected stage, and stained negatively for inhibin- $\alpha$ [7]. Heterologous mesenchymal or neuroblastic components have been described in rare Sertoli-Leydig cell tumors but were not present in this case [8]. Although most ovarian stromal tumors express inhibin- $\alpha$, this tumor did not; however, this does correlate with the clinical studies showing increased serum levels of inhibin- $\beta$ but normal levels of inhibin- $\alpha$ [9].

Although the etiology of this patient's developmental delay is unclear, its coincidence with this tumor is intriguing. She was born at 39 weeks of gestation, a 3,610-g product of a pregnancy complicated by non-insulin-dependent gestational diabetes mellitus and mild gestational hypertension. She had an accessory finger that was surgically removed shortly after birth, short fingernails, bilateral clinodactyly, broad thumbs, and large toes. Her mild dysmorphic facial features included synophrys, narrow palpebral fissures, a short forehead, bilateral epicanthal folds and a narrow nasal bridge, heterochromic irides, normally set ears with underdeveloped helical groups, and low anterior and posterior hairlines. The patient also had a pigmented, $2.0-\mathrm{cm}$ birthmark under her left axilla. Ophthalmologic examination was unremarkable and showed no signs of retinal degeneration. At 12 months of age, she was at the $95_{\text {th }}$ percentile for weight despite being at the $50_{\text {th }}$ percentile for height, and she has remained above the $95_{\text {th }}$ percentile for weight ever since. She did not walk until age 16 months and never crawled. At 5 years, she possessed a 100-word vocabulary and was just beginning to formulate short sentences. She experienced menarche at age 12 with irregular cycles since then. Laboratory tests for thyroid and pituitary function were within normal limits. Karyotypic and fluorescence in situ hybridization studies of the Prader-Willi critical region were normal. The clinical possibilities included BardetBiedl, Laurence-Moon, and Prader-Willi syndromes. However, no propensity for malignancy has been reported in any of these syndromes. The significance of her family history of frequent gynecologic cancers is unclear in the absence of additional information. A few case reports of similar, histologically diverse ovarian neoplasms have been reported in the pediatric population and suggest sporadic occurrence $[10,11]$.

The final diagnosis was a stage IIIC mixed sex cord-stromal tumor including granulosa cell tumor of adult and juvenile types and intermediateto high-grade Sertoli cell tumor, with large areas of poorly differentiated, atypical cells resembling juvenile granulosa cell tumor. Most patients with sex cord-stromal neoplasms present early with limited involvement and have a good prognosis, with 5-year survival rates of $80 \%$ to $90 \%$ for stage I tumors. However, for this patient and others with extraovarian disease (stage II or greater), 5-year survival rates are much lower, in the range of 33\% to $50 \%[12,13]$. Although the histologic subtype of granulosa cell tumor does not directly correlate with outcome, high nuclear grade, atypia, and mitotic activity are poor prognostic factors related to advanced stage disease and are prevalent in this tumor $[13,14]$. The patient was treated with 6 cycles of a chemotherapy protocol comprised of bleomycin, etoposide, and cisplatin. Fifteen months after her initial diagnosis, she was in clinical remission with negative pelvic ultrasound and computed tomographic examinations, an in- 
hibin-A level lower than $10 \mathrm{pg} / \mathrm{mL}$, and an inhibinB level of $40 \mathrm{pg} / \mathrm{mL}$.

\section{REFERENCES}

1. Young RH, Scully RE. Sex cord-stromal, steroid cell, and other ovarian tumors with endocrine, paraendocrine, and paraneoplastic manifestations. In: Kurman RJ, eds. Blaustein's Pathology of the Female Genital Tract. 5th ed. New York: Springer-Verlag. 1994; p 905-966.

2. Young RH, Dickersin GR, Scully RE. Juvenile granulosa cell tumor of the ovary: a clinicopathological analysis of 125 cases. Am J Surg Pathol 1984;8:575-596.

3. Tavassoli FA, Norris HJ. Sertoli tumors of the ovary: a clinicopathologic study of 28 cases with ultrastructural observations. Cancer 1980;46:2281-2297.

4. Riopel MA, Perlman EJ, Seidman JD, Kurman RJ, Sherman ME. Inhibin and epithelial membrane antigen immunohistochemistry assist in the diagnosis of sex cord-stromal tumors and provide clues to the histogenesis of hypercalcemic small cell carcinomas. Int J Gynecol Pathol 1998;17:46-53.

5. Costa MJ, Ames PF, Walls J, Roth LM. Inhibin immunohistochemistry applied to ovarian neoplasms: a novel, effective, diagnostic tool. Hum Pathol 1997;28:1247-1254.

6. Schneider DT, Janig U, Calaminus G, Gobel U, Harms D. Ovarian sex cord-stromal tumors-a clinicopathological study of 72 cases from the Kiel Pediatric Tumor Registry. Virchows Archiv 2003;443:549-560.
7. McCluggage WG, Sloan JM, Murnaghan M, White R. Gynandroblastoma of ovary with juvenile granulosa cell component and heterologous intestinal type glands. Histopathology 1996;29:253-257.

8. Prat J, Young RH, Scully RE. Ovarian Sertoli-Leydig cell tumors with heterologous elements. II. Cartilage and skeletal muscle: a clinicopathologic analysis of twelve cases. Cancer 1982;50:2465-2475.

9. Ciris M, Erhan Y, Zekioglu O, Bayramoglu H. Inhibin $\alpha$ and $\beta$ expression in ovarian stromal tumors and their histological equivalences. Acta Obstet Gynecol Scand 2004;83: 491-496.

10. Hollenbeck JI, Rodgers BM, Talbert JL, Donnelly WH. Bilateral granulosa cell tumors of the ovaries in infancy. J Pediatr Surg 1978;13:542-543.

11. Tavassoli FA. A combined germ cell-gonadal stromal-epithelial tumor of the ovary. Am J Surg Pathol 1983;7:73-84.

12. Seidman JD. Unclassified ovarian gonadal stromal tumors. A clinicopathologic study of 32 cases. Am J Surg Pathol 1996;20:699-706.

13. Stuart GCE, Dawson LM. Update on granulosa cell tumors of the ovary. Curr Opin Obstet Gynecol 2003;15:33-37.

14. King LA, Okagaki T, Gallup DG, Twiggs LB, Messing MJ, Carson LF. Mitotic count, nuclear atypia, and immunohistochemical determination of Ki-67, p21-ras, c-erbB2, and p53 expression in granulosa cell tumors of the ovary: mitotic count and Ki-67 are indicators of poor prognosis. Gynecol Oncol 1996;61:227-232. 